\title{
Are Forward Exchange Rates Rational Forecasts of Future Spot Rates? An Improved Econometric Analysis for the Major Currencies
}

\author{
Raj Aggarwal \\ University of Akron, U.S.A. \\ Winston T. Lin \\ The State University of New York at Buffalo, U.S.A. \\ Sunil K. Mohanty \\ University of St. Thomas, Minneapolis, U.S.A.
}

\begin{abstract}
It has been suggested that prior studies that have puzzlingly found forward rates to be inefficient and biased forecasts of future spot rates may be limited by inadequate statistical methodologies. Using an improved statistical methodology that accounts for both non-stationarity and non-normality in exchange rates, we unfortunately reconfirm that U.S. dollar forward rates for horizons ranging from one to twelve months for the British pound, Japanese yen, Swiss franc, and the German mark over the period 1973-1998 are generally not efficient or rational forecasts of future spot rates. However, as one bright spot, we cannot reject efficiency and rationality for the U.S. dollar forward rate for the Canadian dollar (JEL: F31, G14, F47, G15).
\end{abstract}

Keywords: forward rates, rational forecasts.

\section{Introduction}

The forward-spot relationship in asset prices continues to be of great interest for investors, portfolio managers, and policy makers. While this relationship is very important from an economic perspective, an

\footnotetext{
${ }^{*}$ We thank S. Papadamou (the discussant at the 2005 MFS) for helpful comments and suggestions. The authors would like to thank session participants at the 2005 Eastern Finance Association, S. Zong, and M. Qi for useful comments but remain responsible for the contents.
}

(Multinational Finance Journal, 2008, vol. 12, no. 1/2, pp. 1-20)

Quarterly publication of the Multinational Finance Society, a nonprofit corporation.

(C) Global Business Publications. All rights reserved.

DOI: $10.17578 / 12-1 / 2-1$ 
important reason why this relationship continues to intrigue us is that in spite of large trading volumes and low trading costs there continue to be seemingly large and persistent deviations from efficiency and rationality. There seems to be consistent empirical evidence that forward rates are simply not efficient or rational forecasts of future spot rates. This is an important puzzle with important economic (e.g., for currency overlay policies in portfolio management) and public policy implications (Aggarwal [2004]).

The efficient markets hypothesis $(E M H)$ has played an important role in understanding asset markets and foreign exchange markets especially in the past few decades. It states that if economic agents are risk neutral; all available information is used rationally; the market is competitive; and there are no taxes, transaction costs, or other frictions; then the foreign exchange market will be efficient in the sense that the expected rate of return to speculation in the forward exchange market will be zero (e.g., Geweke and Feige [1979] and Hansen and Hodrick [1980]). ${ }^{1}$ The $E M H$ also implies that since forward exchange rates fully reflect available information concerning investors' expectations of future spot rates, the forward rates should be unbiased forecasts of future spot rates (see, e.g., Levich [1979], Lin [1999], and Lin et al. [2002], among others). Thus, it is clear that tests of market efficiency are composed of joint tests of two null hypotheses: one is the market efficiency hypothesis $(M E H)$ and the other is the unbiasedness or rational expectations hypothesis $(U H$ or $R E H)$. While the theoretical foundations of the $E M H$ and the $R E H$ seem sound, the vast amount of empirical work that has been undertaken to test the $M E H$ and the $U H$ in the foreign exchange markets has very rarely supported these theoretically elegant hypotheses. ${ }^{2,3}$ In a recent paper (Tauchen [2001]), it has been suggested that due to limitations in the statistical methodologies used in prior studies, the evidence against the hypothesis of unbiased forward rates is much stronger than previously believed.

1. A risk neutral investor needs no compensation for risk and so the future spot rate may not differ from expectation.

2. For the $M E H$, see for example, Geweke and Feige (1979); Hansen and Hodrick (1980); Fama (1984); Hodrick and Srivastava (1986); Hsieh (19840; Wolff (1987); and Sephton and Larsen (1991); Cavaglia, Verschoor, and Wolff (1994).

3. For the $U H$, see, Levich (1979); Kohlhagen (1979); Bilson (1981); Hsieh (1984); Gregory and McCurdy (1984); Cavaglia, Verschoor, and Wolff (1993); Naka and Whitney (1995); Lin (1999); and Lin et al. (2002). 
This study represents an improvement over the existing literature in several ways. We use the cointegration methodology used in Aggarwal, Mohanty, and Song (1995) to test the efficient markets hypothesis or its two implications simultaneously. This methodology features several innovations compared to the statistical procedures used in prior studies of the forward-spot relationship. First, it is built within the framework of the rational expectations hypothesis. Second, the cointegration methodology accounts for non-stationarity and non-normality, widely documented time-series properties of spot and forward exchange rates data. ${ }^{4}$ Third, it estimates a cointegrating factor which is particularly appropriate if the spot and forward rates are cointegrated. Fourth, it is a joint test of efficiency and unbiasedness, the two components embodied in the EMH (Liu and Maddala [1992a, 1992b]). ${ }^{5}$ Fifth, as suggested by Sephton and Larsen (1991), our methodology meets the need for a more thorough analysis of cointegrating regressions and the error correction models used to describe equilibrium relationships. Finally, this paper uses a long sample period from January 1973 (the start of the recent period of floating rates) to December 1998 (the consolidation of the European currencies into the Euro) that covers a wide range of major currencies with forward rates over various forecast horizons (one-, three-, six- and twelve-months). These statistical procedures represent a significant improvement over prior studies of forward rates as forecasts of future spot exchange rates.

Using this improved statistical methodology that accounts and corrects for both non-stationarity and non-normality, we reconfirm that U.S. dollar forward rates for horizons ranging from one to twelve months for the major currencies, the British pound, Japanese yen, Swiss franc, and the German mark, are generally not efficient or rational forecasts of future spot rates (the Canadian dollar is one exception to these generally bleak findings). These findings of inefficiency and non-rationality in forward exchange rates for the major currencies continue to be puzzling especially as these foreign exchange markets are some of the most liquid asset markets with very low trading costs.

4. See, Meese and Singleton (1982); Hakkio and Rush (1989); Barnhart and Szakmary (1991); Liu and Maddala (1992a); Liu and Maddala (1992b); Naka and Whitney (1995); Norrbin and Reffett (1996).

5. Some conflicting conclusions in prior studies of the $E M H / R E H$ in currency markets are attributable to sample periods and/or model specifications indicating the need for a new study using improved methodology. 


\section{Literature Review}

The empirical literature of tests on the validity of the market efficiency may be classified into two groups. One group consists of the tests on the $U H$ and the other is constituted by the tests on the $M E H$. Well-known examples in the first group include the joint tests conducted by Geweke and Feige (1979) which have provided some indications of why foreign exchange markets are not efficient (due to market participants' risk averse behavior and the existence of transaction costs), while Hansen and Hodrick (1980) have rejected the $M E H$ from the 1970s and the 1920s; the semi-strong-form tests undertaken by Longworth (1981) have rejected the joint null hypothesis of an efficient exchange market and no risk premium for the period ending in October 1976. The studies of Fama (1984), Boothe and Longworth (1986), and Hodrick and Srivastava (1986), Hakkio and Rush (1989), Sephton and Larsen (1991), Liu and Maddala (1992a, 1992b) have also failed to support market efficiency hypothesis. Prior studies attributed the failure of market efficiency to several factors such as presence of risk premiums contained in forward rates, the (negative) correlation between the forward risk premia and expected future spot rates, empirical irregularities in regression tests, the measurement of profitable rules, and the lack of use of appropriate econometric techniques.

A great number of studies have also been devoted to testing the $U H$. Lin and Chen (1998), Lin (1999), Lin and Lin (2000), and Lin et al. (2002) have provided somewhat thorough reviews of this empirical literature. Many of these studies have considered only one sample period, one time horizon (mostly one month), and one or more currencies, so that the rejection or acceptance of the $U H$ may depend on the sample periods, currencies, and time horizons under study (Lin [1999]). Some tests have been performed on the basis of the argument that functional forms are exploitable (e.g., Barnhart and Szakmary [1991], Lin [1999], and Lin et al. [2002]). Still others believe that a number of well-cited tests of unbiasedness have suffered from specification error (misspecification), such as structural homogeneity bias arising from the assumption that the slope coefficient of the $U H$ is invariant over time (see, e.g., Lin et al. [2002]). Thus, to correct the bias created by the structural homogeneity assumption, Gregory and McCurdy (1984) have addressed the misspecification issue, Chiang (1988) has taken a stochastic coefficient approach, and Lin (1999) and Lin et al. (2002) have used a logarithmic change specification which is 
transformed into a variable mean response model estimated by a four-step generalized least squares procedure.

Nevertheless, the empirical tests on the $U H$ are inconclusive and conflicting. The $U H$ is supported by a few early studies (e.g., Cornell [1977] and Kohlhagen [1979]), but most of the more recent studies, e.g., Levich (1979), Bilson (1981), Gregory and McCurdy (1984), Hsieh (1984), Lin (1999), Lin et al. (2002), and Chernenko et al (2004), among others, have rejected the $U H$. Similarly, other studies (e.g., [1982], Domowitz and Hakkio [1985], Barnhardt and Szakmary [1991], and Lin and Chen [1998]) have also provided mixed results for the $U H$. This brief review of market efficiency tests clearly points to the need to use improved methodology that is capable of testing the joint null hypothesis of efficiency and unbiasedness for the foreign exchange market. This is what we do in this paper.

\section{Data}

The monthly spot and forward rates for five major currencies, expressed in terms of U.S. dollars, were collected from The Wall Street Journal and the Datastream. They are the rates reported at the end of a month. The forward rate time horizons considered are $m=1,3,6$, or 12 month. The data used cover the period from January 1973 to December 1998, yielding 312 monthly observations for each exchange rate series for a total of 7800 observations. The starting point is chosen to reflect the advent of floating rates and the ending point was dictated by the availability of data for all five currencies examined in this study. These currencies are the Canadian dollar (CN), Swiss frank (FR), German deutshe mark (GM), Japanese yen (JP), and United Kingdom pound sterling (UK).

\section{Model Specifications and Tests of Market Efficiency Hypothesis}

Market efficiency hypothesis in forward exchange markets as defined in Hansen and Hodrick (1980) implies that traders have rational expectations. The rational expectations hypothesis $(R E H)$ states that economic agents should make use of all available information in forming expectations and, thus, there should be no systematic patterns 
in forecast errors, and such errors should be a white noise. Thus, the rational expectations hypothesis asserts that the market's subjective probability distribution for any variable is identical to its objective probability distribution, conditional on all available information. Following Mishkin (1983) and Aggarwal, Mohanty and Song (1995), the appropriate model specification to test the $R E H$ is as follows:

$$
E_{m}\left(S_{j, t+m} \mid \varphi_{t}\right)=E\left(S_{j, t+m} \mid \varphi_{t}\right)
$$

where $\varphi_{t}$

is the set of information available including all present and past values of spot and forward rates at time $t$

$S_{j, t+m} \quad$ is the spot exchange rate for currency $j$ in period $t+m$;

$E_{m}\left(. . \mid \varphi_{t}\right)$ is the subjective expectation assessed by the market;

$E\left(. . \mid \varphi_{t}\right) \quad$ is the objective expectation conditional on $\varphi_{t}$.

Thus, rational expectations, given in equation 1, imply the following condition:

$$
E\left[S_{j, t+m}-E_{m}\left(S_{j, t+m} \mid \varphi_{t}\right) \varphi_{t}\right]=0
$$

Combining equations 1 and 2, the market equilibrium condition can be written as follows:

$$
E\left(S_{j, t+m}-F_{j, t+m} \mid \varphi_{t}\right)=0
$$

where $F_{j, t, m}=E_{m}\left(S_{j, t+m} \mid \varphi_{t}\right)$, the forward exchange rate for currency $j$ in period $t$ for delivery in $m$ periods(months).

The orthogonality condition represented by equation 3 implies two key properties characterizing rational expectations. They are: (i) the forecast errors (the errors resulting from the use of forward rates for forecasting spot rates) conditional on the available information set $\left(\varphi_{t}\right)$, have zero means i.e., the forecasts are unbiased; and (ii) the forecast errors $\left(S_{j, t+m}-F_{j, t, m}\right)$ should be uncorrelated with any information in $\varphi_{t}$, and, therefore, also with their own past values. 


\section{A. Unbiasedness Test}

In this paper, we first focus on unbiasedness test, a necessary pretest before carrying out other tests of market efficiency. To test whether forward rates $\left(F_{j, t, m}\right)$ are unbiased forecasts of future spot rates $\left(S_{j, t+m}\right)$, we use the following model based on Muth (1961):

$$
S_{j, t+m}=\beta_{0}+\beta_{1} F_{j, t, m}+\varepsilon_{j, t, m}
$$

with $\beta_{0}=0$ and $\beta_{1}=1 ; E\left(\varepsilon_{j, t+m}\right)=0$.

As in Muth (1961), $\varepsilon_{j, t+m}$ must be uncorrelated with $F_{j, t, m}$, the expected value. Moreover, the error series $\left(\varepsilon_{t}\right)$ should be characterized by no significant serial correlation. If any of these conditions are not satisfied, then the hypothesis of unbiasedness is rejected.

It is well known that regressing one non-stationary series (random walk) against another such series can lead to spurious results in that conventional significance tests will indicate a relationship between the variables when in fact none exists (e.g., Phillips [1986]). For example, the slope estimate in general, will be downwardly biased when we regress spot rates series having a unit root on a forward rates series having a unit root. In such case, a conventional significance test would lead toward the rejection of null hypothesis of unbiased forecasts. Prior research on the efficiency of the foreign exchange markets provides evidence that spot rates and forward rates are nonstationary and follow unit root processes. ${ }^{6}$ In this paper, we first test whether the spot rates and the forward rates are all $I$ (1) series (integrated of order 1). In such cases, a more appropriate approach is to estimate a cointegrating factor (e.g., Engle and Granger [1987], Phillips and Perron [1988]), which is estimated from the cointegrated regression.

To examine the issue surrounding non-stationarity and unit roots associated with spot and forward rates, we use an augmented Dickey-Fuller $(A D F)$ test which allows for serial correlation in error term $\left(\varepsilon_{j, t+m}\right)$. This is important since unit root tests of spot and forward rates series should take into account any seasonality in the generation of time-series data. The $A D F$ test for unit roots is estimated by running

6. See for example, Meese and Singleton (1982); Baillie and Bollerslev (1989); Hakkio and Rush (1989); Barnhart and Szakmary (1991); Liu and Maddala (1992a, 1992b); Naka and Whitney (1995); Norrbin and Reffett (1996); Lin and Chen (1998) and Lin et al. (2002). 
the following $O L S$ regression: ${ }^{7}$

$$
\begin{gathered}
S_{j, t+m}-S_{j, t-1+m}=\beta_{0}+\beta_{1} S_{j, t-1+m}+\beta_{2} \Delta S_{j, t-1+m} \\
+\beta_{3} \Delta S_{j, t-2+m} \ldots+\beta_{n} \Delta S_{j, t-n+m}+v_{j, t+m}
\end{gathered}
$$

If spot rates $S_{j, t+m}$ and forward rates $F_{j, t, m}$ are non-stationary and follow unit root process, a cointegration test has been suggested. Consistent with Engle and Granger (1987) and Hakkio and Rush (1989), spot rates $\left\{S_{j, t+m}\right\}$ and forward rates $\left.\left\{F_{j, t, m}\right\}\right]$ are said to be cointegrated if they satisfy the following three conditions. First, the spot rates $\left\{S_{j, t+m}\right\}$ and the forward rates $\left\{F_{j, t, m}\right\}$ are non-stationary in levels. Second, both spot and forward rate series $\left(S_{j, t+m}\right.$ and $\left.F_{j, t, m}\right)$ are stationary in first difference. Third, there exists a linear combination of levels, where $u_{j, t+m}$ $=S_{j, t+m}+\beta F_{j, t, m}$ is stationary.

As with the testing of rational expectations hypothesis $(R E H)$, the appropriate tests of the market efficiency hypothesis $(M E H)$ in foreign exchange markets must meet the following three conditions: (i) spot rates $\left(S_{j, t+m}\right)$ and the forward rates $\left(F_{j, t, m}\right)$ must be cointegrated; (ii) the cointegrating factor must be 1 ; and (iii) forecast error must be a white noise process, a special case of a stationary series. In this paper, to test the $M E H$ we use the above restricted cointegration tests along with the $Q$-statistics to test for serial correlation in the residuals.

The cointegrating factor can be estimated by simply running an $O L S$ regression of spot rates $\left(S_{j, t+m}\right)$ on forward rates $\left(F_{j, t, m}\right)$. Stock (1987) shows that if $\left(S_{j, t+m}\right)$ and $\left(F_{j, t, m}\right)$ are cointegrated, then the estimate of $\beta_{1}$ (cointegrating factor) in the regression will possess a superconsistency property such that the estimated coefficient (cointegrating factor) should converge to its true value more quickly than under more general assumptions (e.g., Stock [1987]). However, one problem that exists in the above analysis is that the estimator may be biased and its distribution may not be asymptotically normal (e.g., Phillips and Ouliaris [1990]). Thus, usual inference procedures do not work (e.g., Campbell and Perron [1991]). ${ }^{8}$ Therefore, we need to correct the estimator of the cointegrating regression using the following three-step

7. Lag lengths are chosen based on Schwarz (1978) Information Criterion.

8. For additional details on the advantages and limitations of using cointegration and analysis to assess time series data, see for example, Phillips and Perron (1988), Campbell and Perron (1991), Banerjee and Hendry (1992), and Engle and Granger (1992). 
error correction model (e.g., Engle and Yoo [1987], and Aggarwal, Mohanty and Song [1995]).

Step I. The cointegration regression coefficient is estimated from the equation $4: S_{j, t+m}=\beta_{0}+\beta_{1} F_{j, t, m}+\varepsilon_{j, t+m}$.

Step II. Estimate $\gamma$ and $\delta_{1}$ from the following regression equations:

$$
\begin{gathered}
\Delta S_{j, t+m}=\gamma\left(S_{j, t+m}-\hat{\beta}_{0}-\hat{\beta}_{1} F_{j, t, m}\right)+\beta_{1} \Delta F_{j, t, m} \\
+\beta_{2} \Delta S_{j, t-1+m}+\beta_{3} \Delta F_{j, t-1, m}+\omega_{j, t+m} \\
\omega_{j, t+m}=\delta_{0}+\delta_{1}\left(-\gamma * F_{j, t-1, m}\right)+\mu_{j, t+m}
\end{gathered}
$$

Step III. The correct estimate of cointegration regression coefficient $\left(\beta_{1}\right)$ is given as:

$$
\beta_{1}=\hat{\beta}_{1}+\hat{\delta}_{1}
$$

where the studentized coefficient is given by: $t=\beta_{1} /$ std. $\left(\delta_{1}\right)$.

\section{Empirical Results}

Prior to estimating equation 4 , it is necessary to know whether the spot rates and forward rates follow a random walk. We use Augmented Dickey-Fuller $(A D F)$ tests to evaluate the stationarity of spot and forward rates $\left(S_{j, t+m}\right.$ and $\left.F_{j, t, m}\right)$ for five currencies considered during the full sample period, January 1973 through December 1998. These tests are estimated based on equation 5. The coefficient estimates on the lagged value of the level of spot rates as well as forward rates and their studentized coefficients are reported in table 1 for spot one-month, three-month, six-month and twelve-month-ahead forecast horizons. The $5 \%$ and $1 \%$ critical values are -2.93 and -3.58 , respectively (see tables in Dickey and Fuller [1979]). As can be seen from table 1, the unit root hypothesis for each of these currencies can not be rejected at the 5\% level. Consistent with previous findings, the general conclusion that emerges from these results is that while spot and forward exchange rates are non-stationary, they are stationary in first differences. 
TABLE 1. Unit Root Tests: Spot And Forward Exchange Rates

\begin{tabular}{|c|c|c|}
\hline Currency & Levels & $\begin{array}{l}\text { Augmented Dickey-Fuller } \\
\text { Tests Differences }\end{array}$ \\
\hline \multicolumn{3}{|l|}{ Spot } \\
\hline British Pound & $\begin{array}{l}-0.030 \\
(-2.484)\end{array}$ & $\begin{array}{c}-1.033 \\
(-18.129) * * *\end{array}$ \\
\hline German Mark & $\begin{array}{l}-0.017 \\
(-1.804)\end{array}$ & $\begin{array}{l}-0.9606 \\
(-16.654) * * *\end{array}$ \\
\hline Japanese Yen & $\begin{array}{l}-0.0064 \\
(-0.921)\end{array}$ & $\begin{array}{c}-0.0180 \\
(-17.640) * * *\end{array}$ \\
\hline Canadian Dollar & $\begin{array}{l}-0.005 \\
(-0.835)\end{array}$ & $\begin{array}{c}-1.073 \\
(-18.720) * * *\end{array}$ \\
\hline Swiss Franc & $\begin{array}{l}-0.017 \\
(-1.899)\end{array}$ & $\begin{array}{c}-0.928 \\
(-16.159) * * *\end{array}$ \\
\hline \multicolumn{3}{|l|}{1 Month Forward } \\
\hline British Pound & $\begin{array}{l}-0.026 \\
(-2.531)\end{array}$ & $\begin{array}{c}-0.909 \\
(-15.907) * * *\end{array}$ \\
\hline German Mark & $\begin{array}{l}-0.017 \\
(-1.789)\end{array}$ & $\begin{array}{c}-0.981 \\
(-16.999) * * *\end{array}$ \\
\hline Japanese Yen & $\begin{array}{l}-0.007 \\
(-0.960)\end{array}$ & $\begin{array}{c}-0.950 \\
(-16.441) * * *\end{array}$ \\
\hline Canadian Dollar & $\begin{array}{l}-0.006 \\
(-0.940)\end{array}$ & $\begin{array}{c}-1.106 \\
(-19.285)\end{array} * * *$ \\
\hline Swiss Franc & $\begin{array}{l}-0.0167 \\
(-1.905)\end{array}$ & $\begin{array}{l}-0.9366 \\
(-16.310) * * *\end{array}$ \\
\hline \multicolumn{3}{|l|}{3 Months Forward } \\
\hline British Pound & $\begin{array}{l}-0.026 \\
(-2.548)\end{array}$ & $\begin{array}{c}-0.929 * * \\
(-16.271) * * *\end{array}$ \\
\hline German Mark & $\begin{array}{l}-0.017 \\
(-1.788)\end{array}$ & $\begin{array}{c}-0.988 \\
(-17.126) * * *\end{array}$ \\
\hline Japanese Yen & $\begin{array}{l}-0.007 \\
(-0.954)\end{array}$ & $\begin{array}{c}-0.952 \\
(-16.465) * * *\end{array}$ \\
\hline Canadian Dollar & $\begin{array}{l}-0.008 \\
(-1.110)\end{array}$ & $\begin{array}{c}-1.136 \\
(-19.848) * * *\end{array}$ \\
\hline Swiss Franc & $\begin{array}{l}-0.017 \\
(-1.917)\end{array}$ & $\begin{array}{c}-0.934 \\
(-16.261) * * *\end{array}$ \\
\hline
\end{tabular}


TABLE 1. (Continued)

\begin{tabular}{lcc}
\hline Currency & Levels & $\begin{array}{c}\text { Augmented Dickey-Fuller } \\
\text { Tests Differences }\end{array}$ \\
\hline 6 Months Forward & & \\
British Pound & -0.027 & -0.906 \\
German Mark & $(-2.587)$ & $(-15.870) * * *$ \\
& -0.018 & -1.042 \\
Japanese Yen & $(-1.745)$ & $(-18.093) * * *$ \\
& -0.007 & -1.070 \\
Canadian Dollar & $(-0.914)$ & $(-18.615) * * *$ \\
& -0.008 & -1.143 \\
Swiss Franc & $(-1.123)$ & $(-19.942) * *$ \\
& -0.017 & -0.960 \\
12 Months Forward & $(-1.930)$ & $(-16.714) * *$ \\
British Pound & & -1.031 \\
German Mark & -0.030 & $(-18.116) * * *$ \\
Japanese Yen & $(-2.493)$ & -1.054 \\
Canadian Dollar & -0.019 & $(-18.306) * * *$ \\
Swiss Franc & $(-1.794)$ & -0.990 \\
& -0.006 & $(-17.141) * * *$ \\
& $(-0.914)$ & -1.129 \\
& -0.009 & $(-19.719) * * *$ \\
& $(-1.240)$ & $(-17.379) * * *$ \\
\hline
\end{tabular}

Note: The augmented Dickey-Fuller test is based on the following regression: $S_{j, t+m}$ $-S_{j, t-1+m}=\beta_{0}+\beta_{1} S_{j, t-1+m}+\beta_{2} \Delta S_{j, t-1+m}+\beta_{3} \Delta S_{j, t-2+m} \ldots .+\beta_{\mathrm{n}} \Delta S_{j, t-n+m}+v_{j, t+m}$. The variable $S_{j, t+m}$ $=$ Time series exchange data. Value of $t$-ratio is reported in parentheses. The $5 \%$ and $1 \%$ critical values for the Dickey-Fuller (1976) tests are -2.89 and -3.14 , respectively.

** Evidence of rejection of a unit root at the $5 \%$ level. *** Evidence of rejection of a unit root at the $1 \%$ level.

We next turn to the cointegration regression tests. Table 2 presents the results of the cointegration tests for all forecast horizons $(m=1,3$, 6 , and 12). Tests of cointegration are simply tests to examine whether the residuals based on regressing $S_{j, t+m}$ on $F_{j, t, m}$ with a constant in equation 4 have unit roots. As can be seen from table 2, the null hypothesis of no-cointegration can be rejected at the $5 \%$ level of significance for all exchange rates with the exception of six-month and twelve-month-ahead forecasts for the Swiss Franc (SF). We find that for all forecast horizons ( $m=1,3,6$ and 12$)$ forward rates and spot rates are 
TABLE 2. Co-integration Tests

\begin{tabular}{|c|c|c|c|c|}
\hline \multirow[b]{2}{*}{ Currency/Horizon } & \multicolumn{3}{|c|}{$\begin{array}{c}\text { Augmented Dickey-Fuller Tests } \\
\Delta U_{t}=\varphi_{0}+\varphi_{1} u_{t-1}+\varphi_{2} \Delta u_{t-1}+\varphi_{3} \Delta_{t-2}+v_{t}\end{array}$} & \multirow[b]{2}{*}{ Month $=12$} \\
\hline & Month = 1 & Month $=3$ & Month $=6$ & \\
\hline British Pound & $\begin{array}{l}-0.975 * * * \\
(-9.970)\end{array}$ & $\begin{array}{l}-0.630 * * * \\
(-7.682)\end{array}$ & $\begin{array}{l}-0.331 * * * \\
(-5.499)\end{array}$ & $\begin{array}{l}-0.059 * * \\
(-3.104)\end{array}$ \\
\hline German Mark & $\begin{array}{l}-0.851 * * * \\
(-9.103)\end{array}$ & $\begin{array}{l}-0.707 * * * \\
(-8.123)\end{array}$ & $\begin{array}{l}-0.491 * * * \\
(-6.578)\end{array}$ & $\begin{array}{l}-0.269 * * * \\
(-4.766)\end{array}$ \\
\hline Japanese Yen & $\begin{array}{l}-0.663 * * * \\
(-8.333)\end{array}$ & $\begin{array}{l}-0.516^{* * * *} \\
(-7.208)\end{array}$ & $\begin{array}{l}-0.462 * * * \\
(-6.632)\end{array}$ & $\begin{array}{l}-0.209 \text { *** } \\
(-4.393)\end{array}$ \\
\hline Canadian dollar & $\begin{array}{l}-0.896 * * * \\
(-9.880)\end{array}$ & $\begin{array}{l}-0.686^{* * * *} \\
(-8.278)\end{array}$ & $\begin{array}{l}-0.401 * * * \\
(-6.100)\end{array}$ & $\begin{array}{l}-0.205 \text { *** } \\
(-4.307)\end{array}$ \\
\hline Swiss Franc & $\begin{array}{l}-0.435 \text { *** } \\
(-6.203)\end{array}$ & $\begin{array}{l}-0.108 * * \\
(-3.116)\end{array}$ & $\begin{array}{l}-0.055 \\
(-2.403)\end{array}$ & $\begin{array}{l}-0.0417 \\
(-2.3132)\end{array}$ \\
\hline
\end{tabular}

Note: Value of $t$-ratio is reported in parentheses. The $5 \%$ and $1 \%$ critical values for the Dickey-Fuller tests are -2.90 and -3.58 respectively. $S_{j, t+m}=$ Spot exchange rates and $F_{j, t, m}=$ Forward exchange rates. $U_{t}$ is the residual from regression $S_{j, t+m}$ on $F_{j, t, m}$.

** Rejection of null hypothesis of no cointegration at the $5 \%$ level. *** Rejection of null hypothesis of no cointegration at the $1 \%$ level.

cointegrated in the case of British Pound (BP), German Mark (DM), Japanese Yen (YEN), and the Canadian Dollar (CD). By contrast, in the case of the Swiss Franc (SF), spot and forward rates are cointegrated only for one-month and three-month-ahead forecast horizons $(m=1$ and 3$)$. With the exception of 6-, and 12- month-ahead forecasts for Swiss Franc, our results suggest that there exists a long-run or equilibrium relationship between the forward rates and the corresponding future spot rates. Thus, the spot rate $\left(S_{j, t+m}\right)$ and the forward rate $\left(F_{j, t, m}\right)$ series for these cases do not drift too far apart from each other over time, i.e., $\left(S_{j, t+m}\right)$ and $\left(F_{j, t, m}\right)$ are long-term convergent (e.g., Engle and Granger [1992]).

Tests of $M E H$ also require that the cointegrating factor be unity. The cointegrating factor is estimated by running an $O L S$ regression of spot rates $\left(S_{j, t+m}\right)$ on forward rates $\left(F_{j, t, m}\right)$. As mentioned earlier, the $O L S$ estimation method might suffer from mis-specification error because the distribution of the $O L S$ estimator of the cointegrating (regression) factor is not asymptotically normal so that the cointegrating factor estimated from the $O L S$ regression is likely to be biased. Therefore, the null hypothesis of unbiasedness of the forward rate as a predictor of the future spot rate is likely to be rejected. We correct the bias in the 
cointegrating factor following the error correction model suggested by Engle and Yoo (1987) and Aggarwal, Mohanty and Song (1995).

Table 3 presents cointegration regression results for all forecast horizons ( $m=1,3,6$, and 12) using the $O L S$ estimator (column 2$)$ and the corrected estimator (column 3) based on the three-step error correction model. Results reported in table 3 (column 3) for 1-month-ahead forecast horizon show that the null hypothesis of the cointegrating factor being unity is rejected at the 5\% significance level for British, German and Switzerland foreign exchange rates. In contrast, the corrected estimators for 3-month-ahead forecast horizon suggest that the null hypothesis of unbiasedness (i.e., cointegrated factor equal to 1) is rejected at the 5\% significance level for British, German and Japanese exchange markets. Examining the corrected estimates of the cointegrating factors for both 6-, and 12-month-ahead forecast horizons, we notice that the cointegrating factor is significantly different from unity at the 5\% significance level for both British and Japanese foreign exchange markets. Please note that the estimated cointegrating factors for 6- and 12- month ahead forecast horizon for the Swiss frank are not estimated as the spot and forward rates have been found to be not cointegrated. Our test results show that only the corrected cointegrating factor for all forecast horizons for Canadian Dollars is not significantly different from unity, providing support for $U H$ hypothesis for the forward exchange rate for the Canadian dollar. Test results for all other currencies provide mixed results. For each of the 1-, 3-, 6- and 12-month-ahead forward exchange rates for British pound indicate that forward rate is a biased indicator of the future spot rate. While the $U H$ for 6- and 12- month-ahead forward rates can not be rejected, the $U H$ for the 1- and 3-month-ahead forward rates is rejected for the German mark. With the exception of the 1-month ahead forward rate, the $U H$ is rejected for all other horizons for the Japanese yen. Similarly, while the $U H$ for 3- month-ahead forward rate can not be rejected, the results for 1-month-ahead forward rate do not provide support for $U H$ for the Swiss frank. In general, except for the Canadian dollar, there is little support for the $U H$ among the other major currencies.

The acceptance of $M E H$ not only requires that the spot rates $\left(S_{j, t+m}\right)$ and the forward rates $\left(F_{j, t, m}\right)$ are cointegrated and the cointegrating factor must be 1, but also that the forecast errors in the forward rate forecasts of the future spot rate must be a white noise. We analyze each of the five currencies and four forecast horizons for which the cointegration analysis for testing $M E H$ is appropriate. In table 4 we report $Q$-statistics 
TABLE 3. Test for Co-integrating Factor $\left(H_{0}: \beta_{1}=1\right)$

\begin{tabular}{|c|c|c|}
\hline \multirow[b]{2}{*}{ Currency } & \multicolumn{2}{|c|}{ Cointegration regression: $S_{j, t+m}=\beta_{0}+\beta_{\mathrm{t}} F_{j, t, m}+E_{j, t+m}$} \\
\hline & Estimated Coefficient $\left(\beta_{1}\right)$ & Corrected Coefficient $\left(\beta_{1}\right)$ \\
\hline \multicolumn{3}{|l|}{ Month $=1$} \\
\hline \multirow[t]{2}{*}{ British Pound } & $1.0108 * * *$ & $1.0104 * * *$ \\
\hline & $(0.0042)$ & $(0.0030)$ \\
\hline \multirow[t]{2}{*}{ German Mark } & 0.9967 & $0.9867 * * *$ \\
\hline & $(0.0072)$ & $(0.0035)$ \\
\hline \multirow{2}{*}{ Japanese Yen } & 0.9991 & 0.9970 \\
\hline & $(0.0037)$ & $(0.0028)$ \\
\hline \multirow[t]{2}{*}{ Canadian Dollar } & 1.0056 & 1.0046 \\
\hline & $(0.0043)$ & $(0.0037)$ \\
\hline \multirow[t]{2}{*}{ Swiss Franc } & $1.0030 * * *$ & $1.0026 * *$ \\
\hline & $(0.0011)$ & $(0.0012)$ \\
\hline \multicolumn{3}{|l|}{ Month $=3$} \\
\hline \multirow[t]{2}{*}{ British Pound } & $1.0180 * * *$ & $1.0173 * * *$ \\
\hline & $(0.0050)$ & $(0.0046)$ \\
\hline \multirow[t]{2}{*}{ German Mark } & $(1.0030)$ & $0.9916 * *$ \\
\hline & $(0.0076)$ & $(0.0043)$ \\
\hline \multirow[t]{2}{*}{ Japanese Yen } & 0.9934 & $0.9906 * * *$ \\
\hline & $(0.0039)$ & $(0.0034)$ \\
\hline \multirow[t]{2}{*}{ Canadian Dollar } & 1.0076 & 1.0070 \\
\hline & $(0.0047)$ & $(0.0046)$ \\
\hline \multirow[t]{2}{*}{ Swiss Franc } & 1.0035 & 1.0000 \\
\hline & $(0.0022)$ & $(0.0053)$ \\
\hline \multicolumn{3}{|l|}{ Month $=6$} \\
\hline \multirow[t]{2}{*}{ British Pound } & $1.0258 * * *$ & $1.0231 * * *$ \\
\hline & $(0.0064)$ & $(0.0083)$ \\
\hline \multirow[t]{2}{*}{ German Mark } & 1.0118 & 0.9949 \\
\hline & $(0.0090)$ & $(0.0068)$ \\
\hline \multirow[t]{2}{*}{ Japanese Yen } & $0.9843 * * *$ & $0.9800 * * *$ \\
\hline & $(0.0046)$ & $(0.0042)$ \\
\hline \multirow[t]{2}{*}{ Canadian Dollar } & 1.0075 & 1.0063 \\
\hline & $(0.0057)$ & $(0.0080)$ \\
\hline \multicolumn{3}{|l|}{ Swiss Franc * } \\
\hline \multicolumn{3}{|l|}{ Month $=12$} \\
\hline \multirow[t]{2}{*}{ British Pound } & 1.0082 & $0.9731 * * *$ \\
\hline & $(0.0070)$ & $(0.0089)$ \\
\hline \multirow[t]{2}{*}{ German Mark } & 1.0116 & 0.9859 \\
\hline & $(0.0111)$ & $(0.0127)$ \\
\hline \multirow[t]{2}{*}{ Japanese Yen } & $0.9669 * * *$ & $0.9602 * * *$ \\
\hline & $(0.0055)$ & $(0.0074)$ \\
\hline \multirow{2}{*}{ Canadian Dollar } & 1.0047 & 1.0013 \\
\hline & $(0.0077)$ & $(0.0165)$ \\
\hline Swiss Franc * & & \\
\hline
\end{tabular}

Note: Estimated coefficient is based on the cointegration regression. Corrected coefficient is based on the three-step error correction model suggested by Engle and Yoo (1987). ** Cointegrating factor significantly different from unity at 5\% level. *** Cointegrating factor significantly different from unity at $1 \%$ level. 
that test for serial correlation in the forecast errors. The critical values for the $Q(1), Q(2), Q(3), Q(4), Q(6)$ and $Q(12)$ statistics are 3.84, 5.99, $7.81,9.49,12.59$, and 21.03 , respectively at the 5 percent significance level. Our results indicate that $Q$-statistics are significant for most cases and that there is significant serial correlation in the residuals. Although evidence from the cointegration tests suggests that the unbiasedness hypothesis for the forward exchange rates is not rejected for most cases, the significant $Q$-statistics associated with forecast errors suggest the rejection of the market efficiency hypothesis.

Our results are consistent with prior literature which suggests that the seeming failure of market efficiency is probably attributable to either expectational errors or risk premia or both. A number of studies since Fama (1984) have suggested that risk premia in the foreign exchange markets may be time-varying accounting for the failure of the $M E H$ and the $R E H .{ }^{9}$ A second explanation for these failures has centered on expectational errors. For example, Frenkel and Froot (1987) provide evidence that investors in foreign exchange market may not have rational expectations. Prior studies also suggest (e.g., Frenkel [1981], and Ott and Veugelers [1986]) that forward exchange rates which predict future spot exchange rates are influenced by changes in interest and inflation rates differentials and monetary policy changes between countries. These studies imply that the changes in expectations between the time that forward rate prediction is made and the spot rate is observed explain partly the forecast errors. For example, unanticipated changes in interest rate differentials between time $t$ and $t+m$ could lead to expectational errors. While the reasons for deviations from the $M E H$ and the $R E H$ remain a topic for future research, using an improved statistical methodology, this study clearly confirms that both hypotheses are violated in most foreign exchange markets - the puzzle continues! However, given the similarity in economic and monetary policies between Canada and the U.S. and that we cannot reject efficiency and rationality for the U.S. dollar forward rate for the Canadian dollar, it indicates that future research on this topic may usefully examine international differences in monetary and economic policies as possible sources of these deviations from efficiency and rationality.

9. Unlike other asset markets, the concept of risk premia in foreign exchange markets is particularly difficult to apply consistently as a currency value is denominated in terms of another currency so that what would be a risk premium for the holder of one currency would be a risk "discount" for the holder of the other currency in a foreign exchange. 
TABLE 4. $Q$-statistics for Forecast Errors

\begin{tabular}{|c|c|c|c|c|}
\hline \multicolumn{5}{|l|}{ A. Month $=1$} \\
\hline Currency & $Q(1)$ & $Q(3)$ & $Q(6)$ & $Q(12)$ \\
\hline British Pound & 0.877 & 1.020 & 2.472 & 2.894 \\
\hline German Mark & 0.004 & 1.188 & 4.343 & 19.175 \\
\hline Japanese Yen & 0.017 & 4.753 & $14.848 * *$ & $58.618 * *$ \\
\hline Canadian Dollar & 0.652 & 6.999 & 7.455 & $27.011 * *$ \\
\hline Swiss Franc & $24.715^{* *}$ & $28.762 * *$ & $34.114 * *$ & $44.149 * *$ \\
\hline \multicolumn{5}{|l|}{ B. Month $=3$} \\
\hline British Pound & $10.459 * *$ & $11.623 * *$ & $12.552 * *$ & $15.938 * *$ \\
\hline German Mark & 0.115 & 2.184 & 5.683 & 5.736 \\
\hline Japanese Yen & 0.442 & 0.816 & $9.608 * *$ & $10.218 * *$ \\
\hline Canadian Dollar & $5.901 * *$ & $16.743 * *$ & $16.861 * *$ & $18.567 * *$ \\
\hline Swiss Franc & $46.873 * *$ & $47.54 * *$ & $47.542 * *$ & $47.601 * *$ \\
\hline \multicolumn{5}{|l|}{ C. Month $=6$} \\
\hline British Pound & $26.307 * *$ & $26.597 * *$ & $26.683 * *$ & $30.442 * *$ \\
\hline German Mark & 3.100 & 7.687 & $15.722 * *$ & $16.768 * *$ \\
\hline Japanese Yen & $6.853 * *$ & $6.917 * *$ & $12.427 * *$ & $12.704 * *$ \\
\hline Canadian Dollar & $21.321 * *$ & $36.84 * *$ & $36.876 * *$ & $41.269 * *$ \\
\hline \multicolumn{5}{|l|}{ D. Month $=12$} \\
\hline British Pound & 0.005 & 0.436 & 6.235 & 6.318 \\
\hline German Mark & $16.648 * *$ & $19.134 * *$ & $27.283 * *$ & $28.281 * *$ \\
\hline Japanese Yen & $18.893 * *$ & $24.557 * *$ & $31.730 * *$ & $31.730 * *$ \\
\hline Canadian Dollar & 44.995 & 59.605 & 60.564 & 64.317 \\
\hline
\end{tabular}

Note: The 5\% significant levels for $Q$-statistics: $Q(1), Q(2), Q(3)$, and $Q(4)$ are 3.84 , $5.89,7.81$, and 9.49. Month 1 estimates go up to 12 lags while the others go up to 4 lags. ** Indicates rejection of no serial correlation in forecast errors at the $5 \%$ level.

\section{Conclusions}

In spite of high liquidity and low trading costs, forward exchange rates are not efficient or rational forecasts of future spot rates. These results have been a puzzle for many years and in spite of numerous empirical studies. It had been suggested that these puzzling results may be due to the use of inadequate statistical methodologies in prior studies. This study uses a new and improved statistical methodology to examine the efficiency and rationality of forward exchange rates as forecasts of future spot rates. It uses data over a long period (1973-1998) and for 
forecast horizons ranging from one to twelve months for the major industrialized nation currencies.

Using this improved statistical methodology this study reconfirms significant deviations from efficiency and rationality for the U.S. dollar forward rate as a forecast of the future spot rate for the British pound, Japanese yen, Swiss franc, and the German mark. However, as one bright spot, we cannot reject efficiency and rationality for the U.S. dollar forward rate for the Canadian dollar.

\section{References}

Aggrawal, R.; Mohanty, S.; and Song, F. 1995. Are survey forecasts of macroeconomic variables rational? Journal of Business 68 (1): 99-118.

Aggarwal, R. 2004. Puzzles in international economics and finance: Central Bank of Ireland Edgeworth Keynote Lecture. Economic and Social Review 35 (1): 241-250.

Baillie, R. T., and Bollerslev, T. 1989. Common stochastic trends in a system of exchange rates. Journal of Finance 44: 167-181.

Banerjee, A., and Hendry, D. F. 1992. Testing integration and cointegration: An overview. Oxford Bulletin of Economics and Statistics 54: 225-255.

Barnhart, S., and Szakmary, A. C. 1991. Testing the unbiased forward rate hypothesis: Evidence on unit roots, co-integration, and stochastic coefficients. Journal of Financial and Quantitative Analysis 26: 245-267.

Bilson, J. F. O. 1981. The speculative efficiency hypothesis. Journal of Business 54: 435-451.

Boothe, P, and Longworth, D. 1986. Foreign exchange market efficiency: Implications of recent empirical findings. Journal of International Money and Finance 5: 135-152.

Campbell, J. Y., and Perron, P. 1991. Pitfalls and opportunities: What macroeconomists should know about unit roots. NBER Macroeconomics. Cambridge, Mass: National Bureau of Economic Research, 141-201.

Cavaglia, S.; Verschoor, W. F. C.; and Wolff, C. C.P. 1993. Further evidence on exchange rate expectations. Journal of International Money and Finance 12: 78-98.

Cavaglia, S.; Verschoor, W. F. C.; and Wolff, C. C. P. 1994. On the biasedness of forward foreign exchange rates: Irrationality or risk premia? Journal of Business 67: 321-343.

Chernenko, S. V.; K. B. Schwartz; and J. H. Wright. 2004. .The Information content of forward and futures prices: Market expectations and the price of risk. International Finance Discussion Paper No. 808, Board of Governors of the Federal Reserve System, Washington, DC.

Chiang, T. C. 1988. The forward rate as a predictor of the future spot rate: A 
stochastic coefficient approach. Journal of Money, Credit, and Banking 20: 212-232.

Cornell, B. 1977. Spot rates, forward rates, and exchange market efficiency. Journal of Financial Economics 5: 55-65.

Dickey, D. A., and Fuller, W. A. 1979. Distribution of the Estimators for autoregressive time series with a unit root. Journal of the American Statistical Association 74: 427-431.

Domowitz, I., and Hakkio, C. S. 1985. Conditional variance and the risk premium in the foreign exchange market. Journal of International Economics 19: 47-66.

Edwards, S. 1982. Exchange Rates and 'News': A multi-currency approach. Journal of International Money and Finance 1: 211-224.

Engle, R. F., and Granger, C. W. J. 1987. Cointegration and error correction: Representation, estimation, and testing. Econometrica 55: 351-276.

Engle, R. F., and Granger, C. W. J. 1992. Long Run Economic Relationships: Readings in Cointegration. New York: Oxford University Press.

Engle, R. F., and Yoo, B. S. 1987. Cointegrating economic time series data: An overview with new results. Presented at the European Meeting of the Econometric Society, Copenhagen, August 24-28.

Fama, E. F. 1984. Forward and spot exchange rates. Journal of Monetary Economics 14: 319-338.

Frenkel, J. A. 1981. Flexible exchange rates, prices and the role of 'news': Lessons from the 1970s. Journal of Political Economy.

Frenkel, J. A., and Froot, K. A. 1987. Using survey data to test standard propositions on exchange rate expectations. American Economic Review 77: 133-153.

Fuller, W. A. 1976. Introduction to Statistical Time Series. New York: Wiley.

Geweke, J., and Feige, E. 1979. Some joint tests of the efficiency of markets for forward foreign exchange. Review of Economics and Statistics 61:334-341.

Gregory, A. W., and McCurdy, T. H. 1984. Testing the unbiasedness hypothesis in the forward foreign exchange market: A specification analysis. Journal of International Money and Finance 3: 357-368.

Hakkio, C. S., and Rush, M. 1989. Market efficiency and cointegration: An application to the sterling and deutschemark exchange markets. Journal of International Money and Finance 8: 75-88.

Hansen, L. P., and Hodrick, R. J. 1980. Forward exchange rates as optimal predictors of future spot rates: An econometric analysis. Journal of Political Economy 88: 829-853.

Hodrick, R. J., and Srivastava 1986. The covariance of risk premiums and expected future spot exchange rates. Journal of International Money and Finance 5: 5-21.

Hsieh, D. A. 1984. Tests for rational expectations and no-risk premium in forward exchange markets. Journal of International Economics 18: 173-184. 
Kohlhagen, S. W. 1979. The forward rate as an unbiased predictor of the future spot rate. Columbia Journal of World Business 14: 77-85.

Levich, R. M. 1979. Are forward exchange rates unbiased predictors of future spot rates? Columbia Journal of World Business 14: 49-61.

Lin, W. T., and Chen, Y. H.1998. Forecasting foreign exchange rates with an intrinsically nonlinear dynamic speed of adjustment model. Applied Economics 30: 295-312.

Lin, W. T. 1999. Dynamic and Stochastic instability and the unbiased forward rate hypothesis: A variable mean response approach. Multinational Finance Journal 3: 173-221.

Lin, H. J., and Lin, W. T. 2000. A dynamic and stochastic beta and its implications in global capital markets. International Finance 3: 123-160.

Lin, W. T.; Lin, H. J.; and Chen, Y. H. 2002. The dynamics and stochastics of currency betas based on the unbiasedness hypothesis in foreign exchange markets. Multinational Finance Journal 6: 176-195.

Liu, P. C., and Maddala, G. S. 1992a. Rationality of survey data and tests for market efficiency in the foreign exchange markets. Journal of International Money and Finance 11: 366-381.

Liu, P. C., and Maddala, G. S. 1992b. Using survey data to test market efficiency in the foreign exchange markets. Empirical Economics 17: 303-314.

Longworth, D. 1981. Testing the efficiency of the Canadian-U.S. exchange market under the assumption of no risk premium. Journal of Finance 36: 43-49.

Meese, R. A., and Singleton, K. J. 1982. On the unit roots and the empirical modeling of exchange rates. Journal of Finance 37: 1029-1035.

Mishkin, F. S. 1983. A rational expectations approach to macro-econometrics: Testing policy ineffectiveness and efficient-markets models. Chicago: University of Chicago Press.

Muth, J. 1961. Rational expectations and the theory of price movements. Econometrica 29: 299-306.

Naka, A., and Whitney G. 1995. A re-examination of the unbiased forward rate hypothesis. Journal of International Money and Finance 14: 857-867.

Norrbin, S. C., and Reffett, K. L. 1996. Exogeneity and forward rate unbiasedness. Journal International Money and Finance 15: 267-274.

Ott, M., and Veugelers, P. T. W. M. 1986. Forward Exchange rates in efficient markets: The effects of news and changes in monetary policy regimes. Review, Federal Reserve Bank of St. Louis 68: 5-15.

Phillips, P. C. B. 1986. Understanding spurious regressions in econometrics. Journal of Econometrics 33: 311-340.

Phillips, P. C. B., and Perron, P. 1988. Testing for a Unit root in time series regression. Biometrika 75: 335-346.

Phillips, P. C. B., and Ouliaris, S. 1990. Asymptotic properties of residual based tests from cointegration. Econometrica 58: 165-193. 
Sephton, P. S., and Larsen, H.K. 1991. Tests of exchange market efficiency: Fragile evidence from cointegration tests. Journal of International Money and Finance 10: 561-570.

Schwarz, G. 1978. Estimating the dimension of a model. Annals of Statistics 6: 461-464.

Stock, J. H. 1987. Asymptotic properties of least squares estimators of cointegrating vectors. Econometrica 55: 1035-1056.

Tauchen, G. 2001. The bias of tests for a risk premium in forward exchange rates. Journal of Empirical Finance 8 (5): 695-704.

Wolff, C. C. P. 1987. Forward foreign exchange rates, expected spot rates, and premia: A signal-extraction approach. Journal of Finance 42: 395-406.

Zarnowitz, V. 1985. Rational expectations and macroeconomic forecasts. Journal of Business and Economic Statistics 3: 293-311. 